\title{
Implementation of Education Quality Assurance in Order to Improve School Quality at SMK Mekarmukti Garut
}

\author{
Sudarajat AM ${ }^{1)}$, Soeganda Priyatna ${ }^{2)}$, Ida Tedjawiani ${ }^{3)}$, R. Supyan Sauri ${ }^{4)}$ \\ 1,2,3,4) Pascasarjana UNINUS Bandung \\ *Coresponding Author \\ Email : ajatsudrajat24@gmail.com
}

\begin{abstract}
This research describe about Education Quality Assurance System is the entire function of education management that develops the duties and responsibilities in measuring and assessing the fulfillment of quality standards. SMK Mekarmukti Garut is one of the schools that has implemented the Primary and Secondary Education Quality Assurance System, which is in accordance with the established indicators, namely the Eight National Education Standards.
\end{abstract}

\section{Keywords: Education Quality Assurance, School Quality}

\section{INTRODUCTION}

Education is a conscious and planned effort to create a learning atmosphere and learning process so that students actively develop their potential to have religious spiritual strength, noble character, and skills needed by themselves, society, nation and state (UU UU No.20 Tahun 2003, Pasal 1 ayat (1). The process of forming the potential of students is one of them formed through education, because in the learning process students are instilled various values, be it state, religion, culture, skills and others. The quality of education is the orientation in the implementation of education by all education stakeholders. Be it the central government, local governments, educational institutions, and the community. This becomes very important when there are still many problems caused by unqualified graduates. Various programs and efforts to improve the quality of education have been carried out by the government, but have not been able to improve the quality of education in Indonesia.

Education is one of the efforts to develop Human Resources (HR), both formal and non-formal education as well as to create human beings who are knowledgeable, faithful, devoted, and skilled so that they can develop all the potential that exists in themselves. National Education functions to develop the abilities of students and improve the quality of education and Indonesian human dignity. In the context of realizing the goals of national education, every citizen has the same right to obtain quality education. Educational problems in general are always faced with problems of equity, relevance, and quality of education. Various efforts to improve the quality of life carried out by humans require serious handling through careful thinking by applying advances in science and technology.

The ability to improve these qualities has long been pursued by humans in various efforts. This activity is known as quality assurance, which is an effort to improve service quality by prioritizing customer satisfaction in carrying out educational interactions. The problem of the quality of education in educational units does not stand alone, but is related in a system that influences each other. The output of education is influenced by the quality of the input and the quality of the teaching and learning process.

In the educational process, each sub-element influences each other. The components that need to be considered in quality development and which must be evaluated are inputs, processes, 
learning outcomes, and the benefits of the results later. The input, in this case the students, is influenced by the students' cognitive, socio-economic conditions, and the environmental conditions in which students live. Then enter an educational institution (school), then students will receive learning from a teacher (educator). The learning process does not only pay attention to cognitive aspects but also pays attention to aspects of moral character and personality, so that students not only have intelligence in thinking but also have good morals and character.

As an effort to improve the quality of education, the government through the ministry of education and culture issued a policy regarding education quality assurance Permendikbud No. 28 of 2016. The government's efforts to ensure education quality are implemented into the Education Quality Assurance System.

The Education Quality Assurance System is divided into two parts, namely, the Internal Quality Assurance System (SPMI) and the External Quality Assurance System (SPME). The Internal Quality Assurance System (SPMI) is a unitary element consisting of related policies and processes to carry out an Education Quality Assurance System implemented by each primary and secondary education unit to ensure the realization of quality education that meets or exceeds the National Education Standards, while the External Quality Assurance (SPME) is a quality assurance system implemented by the government, local governments, accreditation agencies and educational standardization institutions (Permendikbud No.28 of 2016). However, all the activities covered by the ministerial regulation do not yet reflect a comprehensive quality management system that touches all aspects of quality assurance. Quality management that is widely campaigned for is the application of a management system that has not really touched the real quality side and its implementation is still limited to the consistency and suitability of administrative documents for educational unit activities.

All of these quality assurance activities refer to the standard provisions set by the government, namely the National Education Standards. For this reason, an effort is needed to encourage and motivate school members and all education stakeholders to be more familiar with and learn the concept of quality and various approaches, techniques and innovations related to quality. The quality management system as an approach in realizing a quality assurance program is very important to be placed as scientific studies in the context of measuring and predicting the readiness of educational institutions. Quality education can be demonstrated by the ability to create an effective and efficient educational process or school management process, therefore the existing resources must be truly professional.

In this case the school as an institution that carries out the educational process in a micro order occupies an important position because in this institution every member of the community can fill the educational process with the aim of preparing them with various knowledge and skills to be more able to play a role in people's lives.

School quality is a representation of the performance of all available resources in schools in carrying out their duties as an effort to realize school goals. School quality is obtained from the overall performance of interrelated school resources, namely: principals, educators, education staff, students, and school committees. School quality is influenced by the managerial ability of school leaders who function to carry out all school resources to be able to carry out their duties professionally. Schools are institutions that are given the responsibility by the government to provide quality educational services to the community. In relation to these educational services, the government has established the National Education Standards (SNP) as a reference basis for measuring school quality. The dimensions that become the benchmark in assessing school quality are contained in PP No. 32 of 2013. According to Nanang Fattah (2012: 2), Quality is the ability (ability) possessed by a product or service that can meet the needs or expectations and customer satisfaction, in education what is meant by customers can be grouped into two 
namely internal customers (students or students as learner as well as input) and external customers (society and industry). In the process of determining the quality of educational institutions, it is necessary to look at the quality improvement factors from many sides, and not only the satisfaction of the results of the accredited recognition process, but also to have high motivation to improve quality or exceed the quality of the quality standards set by the government. The Internal Quality Assurance System (SPMI) makes schools the main actors or spearheads of education quality assurance SPMI creates schools as learning organizations and creates the importance of a quality culture.

Quality is no longer positioned as a burden but a necessity, even as a lifestyle. The quality of education is now no longer the responsibility of certain parties, but is everyone's business, and expects every school member to actively participate and contribute to improving the quality of education in schools (Puspitasari, 2017: 340-341). In general, the quality assurance system for education/school units is a process of determining and fulfilling quality standards for managing education/school units consistently and sustainably so that all users of graduates (stakeholders) obtain stakeholder satisfaction. The purpose of education quality assurance is to plan, achieve, maintain, and improve the quality of education on an ongoing basis in certain educational units. Every education unit is obliged to carry out education quality assurance in improving the quality of an education in schools. The Education Quality Assurance System is the entire function of education management that develops duties and responsibilities in measuring and assessing the fulfillment of quality standards. SMK Mekarmukti is one of the schools that has implemented the Primary and Secondary Education Quality Assurance System, which is in accordance with the established indicators, namely the Eight National Education Standards. The Primary and Secondary Quality Assurance System is a unified element consisting of an integrated organization, policy, and process that regulates all activities to improve the quality of Elementary and Secondary Education in a systematic, planned and sustainable manner.

In terms of school level, there are eight standards that must be met, namely content standards, process standards, graduate competency standards, infrastructure standards, educators and education personnel standards, management standards, financing standards and assessment standards. In completing the Education Quality Assurance activities In order to improve the quality of schools at SMK Mekarmukti carry out various activities such as planning where to plan what activities to advance the school, how the activities will be carried out and the final evaluation of PMP activities, all done through the formation of work teams and determined through a policy in a meeting attended by the principal, vice principal and all educators (teachers) at SMK Mekarmukti. Furthermore, in the implementation of PMP by filling out all the eight standard assessment instruments from the center, but the obstacles here are some educators who do not understand how to fill out these instruments and the policies from school principals who have given direction to educators still have an impact on the results of the Education Quality Assurance System. in schools have not reached the target.

The duties and roles of school principals in the school accreditation process are very large, especially in building their commitment to improving the quality of school education. Based on the observations made by the authors through the process and results of accreditation, the principal must prove his ability in the form of leadership in coordinating various work with teachers and educators so that they can participate in improving the quality of education in schools. Based on this background, what will be discussed in this paper are: How is the implementation of SPMP in order to improve the quality of schools at SMK Mekarmukti. 


\section{RESEARCH METHODS}

This research was conducted using a qualitative approach. The method used is descriptive analysis. Location and source of research data at SMK Mekarmukti, Garut Regency. Techniques and research instruments using observation, interviews and documentation. While the analysis technique is done through data reduction, data display and drawing conclusions.

\section{RESULTS AND DISCUSSION}

Based on the results of research that has been carried out by the author at SMK Mekarmukti, Garut Regency that schools carry out education quality assurance independently. The education quality assurance system is a systematic activity of quality assurance of education by the education unit to oversee the implementation of education by the education unit itself on an ongoing basis for the satisfaction of education customers. The implementation of the quality of education at the SMK Mekarmukti in Garut Regency is a must to implement, because the quality of education does not only depend on the government but also depends on the assessment that will be accepted by the school institution.

This is in accordance with the PMP Dikdasmen Kemdikbud which states that the implementation of the quality assurance system in the education unit is fully carried out and is the responsibility of the education unit itself without government intervention.

Before implementing the education quality assurance system, SMK Mekarmukti, Garut Regency first formed an internal quality assurance team structure. The team was formed by the school principal accompanied by a decree for the formation of an internal quality assurance team and its working structure. The tasks of this team include: compiling an SNP-based mapping instrument, coordinating the implementation of education quality mapping, analyzing the mapping results, and compiling recommendations for fulfilling the quality of education units based on the quality mapping results. SMK Mekarmukti, Garut Regency has fulfilled the quality in order to achieve the school's vision and mission. As evidence that the SMK Mekarmukti in Garut Regency implements SPMI, the school makes new innovations in the hope of improving the quality of education and teaching in schools.

The implementation of education quality assurance is used to improve the quality of education in the planning stage. The findings in the quality assurance system will be used as input to improve standards and improve for the better. Utilization of the results of the implementation of quality assurance in addition to being used in educational planning, is also used to foster a spirit of better performance, and raise awareness to build a quality culture, so that continuous improvement in the quality of education will be realized.

This was disclosed by the Principal of SMK Mekarmukti, Garut Regency, as follows:

Before implementing quality we must first form a quality assurance team. I, as the principal of SMK Mekarmukti, Garut Regency, formed the team, but yes, I am in accordance with the mutual agreement and I am not pointing at random, only people who have competence related to the quality of education. From the team formed, it has been proven by the existing SK, so that they must carry out their duties. Furthermore, the presentation of the results of interviews with the Deputy Principal of SMK Mekarmukti Garut Regency is as follows:

In my opinion, we have a special team to take care of quality assurance, with the aim that the implementation of fulfilling the quality of education at SMK Mekarmukti, Garut Regency can run well and get results in accordance with what we planned. 
Based on the results of interviews conducted by researchers, it can be concluded that the implementation of this quality assurance system must be structured according to what has been planned. In this case, the principal is responsible for leading and directing all members in collaborating and focusing on the implementation of school quality assurance.

The quality assurance implementation program implemented at SMK Mekarmukti, Garut Regency, with the implementation of the program is needed to foster motivation and as a starting point to provide an understanding of a program. A work team will work tirelessly and will produce an extraordinary work, therefore the background of the education quality assurance program must be instilled in all team members, with the aim of providing motivation in carrying out the duties of each team member.

The implementation of the education quality assurance program is the Minister of National Education Regulation Number 63 of 2009 concerning the Education Quality Assurance System. The purpose of implementing the program is to provide quality educational services to the community. The steps for implementing the education quality assurance program in education units are the fulfillment of eight national education standards that have been stipulated in the Government Regulation of the Republic of Indonesia Number 19 of 2005 concerning National Education Standards. The relationship between SPM, SNP, Accreditation and Quality Assurance when measured by BAN-S (National Accreditation Board for Schools). Whereas efforts to improve quality carried out by schools with accreditation with grades B and A are an effort under the name of the Education Quality Assurance program. After the fulfillment of the eight National Education Standards, of course the quality at SMK Mekarmukti Garut Regency will also be good.

In the research that researchers have done at this school, there are other factors that can indicate whether or not the quality of an education is good, namely the accreditation assessment, which is carried out by the assessor with assessment indicators through eight National Education Standards and 70 other accreditation assessment components. SMK Mekarmukti, Garut Regency, which is currently accredited by BAN-S with an A rating, all efforts to improve school quality are called education quality assurance programs.

Schools that will carry out accreditation are given time to prepare everything needed for accreditation. The implementation of accreditation at SMK Mekarmukti Garut Regency is an effort to improve quality in the field of education, making schools as educational institutions that are required to always strive to improve quality in the implementation of education, so that they can produce quality graduates and be able to compete with stakeholder demands. All components can be prepared in advance, because accreditation includes eight National Education Standards (SNP), namely graduate competency standards, content standards, process standards, management standards, financing standards, infrastructure standards, educators and education personnel standards, and assessment standards.

In order to prepare these 8 standards, directly or indirectly, all components of the school will improve according to the standards that have been set. In accordance with Sallis (2011: 58), quality assurance is an activity carried out with the aim of preventing products from failing or creating products without defects (zero defects). the value of national education standards.

The education quality assurance program at SMK Mekarmukti Garut Regency takes the form of: 1) The division of tasks for educators in delivering learning in class has been established, 2) Addition of lesson hours to the 2013 Curriculum structure that he has set, 3) Purchase and add student handbooks for easier to understand following learning in class, 4) Student selfdevelopment which aims to shape the character and personality of students. The general purpose of self-development is to provide students with opportunities to be able to express and develop their own talents and interests. 
In programmed self-development, students can choose extracurricular provided by SMK Mekarmukti, Garut Regency, namely: scouts, tahfiz Al-Qur'an, arts, and sports.

From the discussion above, the researcher concludes that the implementation of the education quality assurance program at SMK Mekarmukti, Garut Regency is appropriate and able to provide encouragement to all team members who get the burden of the task. However, in the course of time the motivation of team members is sometimes eroded by the demands of the lives of team members, thus it is better if the head of the education quality assurance program team in this case is the principal should always monitor, evaluate the course of the program and make improvements and changes when the principal finds members the team that works or carries out their duties is not in accordance with the concept or deviates from the implementation and objectives of the education quality assurance program.

Thus the activities of the education quality assurance program will always run according to plan. Based on this, the principal explained about whether school accreditation could be an indicator of the quality of education at SMK Mekarmukti, Garut Regency.

Yes of course. The rooteditation assessment that will be carried out looks at how the quality of education in this school is, the assessment also departs from the reality in the school, the accreditation at this SMPN has received an accreditation classification of "A", meaning that the assessment carried out on the quality of education is good.

In line with the above opinion, the vice principal stated that: If the quality of education has been achieved, the quality contained in the eight National Education Standards, this accreditation will be achieved and at least the school will continue to hold on to the predicate it currently has.

In this accreditation assessment, you have to carry out activities that are in the school, the more activities that are carried out to achieve school achievement, it will definitely greatly affect the school's accreditation assessment. If these activities go well, both in the curricular and extracurricular fields, it is achieved.

SMK Mekarmukti Garut Regency already has a special institution in schools in ensuring the quality of education. Schools always evaluate school activity programs to obtain information that can identify the strengths and weaknesses of programs that have been implemented in schools, prepare future school development plans, school performance reports, and things that need to be improved as a form of accountability to the community and government.

\section{CONCLUSION}

Implementation of education quality assurance that has been planned to fulfill eight National Education Standards. The implementation of the quality of education at the SMK Mekarmukti in Garut Regency must be carried out, because the quality of education does not only depend on the Government but also depends on the assessment received by the school. Prior to the implementation of the quality assurance system, the principal forms an education quality assurance team whose task is to carry out all matters relating to the fulfillment of the quality of education so that implementation can run well.

Suggestion

Based on these conclusions, the suggestions that become the recommendations of researchers are as follows:

1. In implementing the quality assurance system, you must first conduct a quality mapping to refer to the eight National Education Standards, so that the implementation of quality assurance can run smoothly and get good EDS results. 
2. After mapping the quality, then the education quality assurance plan must carry out the steps that have been determined by the principal in a joint meeting.

3. Implementation of the quality assurance system first, the principal must form a quality assurance team who understands the performance to be carried out, so that what the school wants to get maximum results or with satisfactory results.

4. For schools, it is hoped that the complete facilities can further improve the quality of education and produce superior students with their achievements and the best graduations. For students of SMK Mekarmukti, Garut Regency, hopefully they will become good graduates as expected by the school, by obeying the rules that have been made by the school or the policies that have been given by the school, it will improve the quality of school education.

5. For the researchers themselves, hopefully this research will be useful for readers. For this research, the writer realizes that it is still far from being perfect. Instead, all competent parties are expected to develop this research.

\section{REFERENCES}

Abdullah,Ridwan Sani, dkk. 2015. Penjaminan Mutu Sekolah. Jakarta: Bumi Aksara

Asmendri. 2012. Teori \& Aplikasi Manajemen Peningkatan Mutu Pendidikan Sekolah dan Madrasah. Batusangkar: Unit Penerbitan dan Publikasi STAIN Batusangkar.

Aulia, Awaludin. 2017. Akreditasi Sekolah sebagai Suatu Upaya Penjaminan Mutu Pendidikan di Indonesia. Jurnal SAP, Vol. 2 No.1.

Asrohah, Hanum. 2014. Manajemen Mutu Pendidikan. Surabaya: UIN Sunan Ampel Press.

Darmaji. 2019. Sistem Penjaminan Mutu Internal Sekolah untuk Meningkatkan Mutu Lulusan. Jurnal Manajemen dan Supervisi Pendidikan, Vol. 3 No.3 Juli 2019.

Departemen Pendidikan Nasional. 2003. Undang-Undang Nomor 20 Tahun 2003 Tentang Pendidikan Nasional, Depdiknas. Jakarta.

Depdiknas. 2002. Manajemen Peningkatan Mutu Berbasis Sekolah; Konsep Dasar. Jakarta: Dikjen Pendidikan Dasar dan Menengah.

Effendi, Alwan. 2017. Manajemen Mutu Pendidikan. Yogyakarta: Media Akademi Engkoswara, dkk. 2015. Administrasi Pendidikan. Bandung: Alfabeta.

Fattah, Nanang. 2012. Sistem Penjaminan Mutu Pendidikan. Bandung: PT Remaja Rosdakarya 